\title{
Cancer Tragedy in this Century and the Role of OMICS Group Open Access Journals in Overcoming this Matter
}

\section{Bassam Abdul Rasool Hassan*}

Clinical Pharmacy Discipline, School of Pharmaceutical Sciences, University of Sains Malaysia, 11800, Minden, Penang, Malaysia

\section{Cancer Background}

During this century, cancer has become one of the major problem and diseases which has caused predominant death and it will even surpass heart diseases. Many of the researchers begin to use the term lifetime risk for cancer patients which refer to the time that cancer will progress and developed or the time that the patient will die because of cancer. Cancer dose not refers or represents only one disease but it is a group involving about 100 diseases. Cancer is characterized by two things. Firstly there is no control for the growth of cancer cells and secondly is the ability of the cancer cells to metastasis and migrates from the original site to different parts of the body. There are two types of tumors which are malignant and benign cancer. Cancer can attack any person and its occurrence increases as the age of the individual increase too $[1,2]$.

\section{Open Access Journal Role in Overcoming this Tragedy}

Open access will play an enthusiastic role in progress and grown up of exchange of experience and this will mainly leads to knowledge grows i.e., as a result of sharing. And this is the main goal for every research in the world i.e., growing up of knowledge [3]. Therefore open access journals role consider the most important specifically for those who work in the field of cancer treatment since all of the open access journals are working to increase their experience relating with cancer treatment which will lead to surmount of cancer and this is the main objective for OMICS Group i.e., help in overcoming cancer in this century since this group publish high quality of open access papers. Moreover OMICS Group is working to spot light on new medical points which may other open access websites do not focus on.

\section{Conclusion}

Open access journal consider as a novel way in improving and developing the knowledge of cancer treatment by increasing exchange of medical information and OMICS group consider as a very supporting group for such new knowledge exchange way i.e., open access journal.

\section{References}

1. Carson-Dewitt R (2002) Cancer. IN LONGE, JL (Ed.) The gale encyclopedia of medicine Farmington Hills, Gale Group.

2. Markman M (2002) Principles of cancer screening. IN AZIZ, K, \& WU, GY (Ed.) Cancer screening A practical guide for physicians New Jersey, Humana Press.

3. Daniel (2008) Open Access is an important step on the way towards open science. World Association of Young Scientists.
*Corresponding author: Bassam Abdul Rasool Hassan, School of Pharmaceutical Sciences, University of Sains Malaysia, 11800, Minden, Penang, Malaysia, Tel: (+6)016-423-0950; Email: bassamsunny@yahoo.com

Received March 04, 2012; Accepted March 07, 2012; Published March 10, 2012

Citation: Rasool Hassan BA (2012) Cancer Tragedy in this Century and the Role of OMICS Group Open Access Journals in Overcoming this Matter. Pharmaceut Reg Affairs 1:e102. doi:10.4172/2167-7689.1000e102

Copyright: (c) 2012 Rasool Hassan BA. This is an open-access article distributed under the terms of the Creative Commons Attribution License, which permits unrestricted use, distribution, and reproduction in any medium, provided the original author and source are credited. 